\title{
PENERAPAN METODE PICTURE AND PICTURE UNTUK MENINGKATKAN PENGUASAAN KOSAKATA BAHASA JEPANG SISWA KELAS X AP 2 SMKN 1 NUSA PENIDA TAHUN AJARAN 2017/2018
}

\author{
I. W. Sudarsana ${ }^{1}$, K. E. K. Adnyani ${ }^{2}$, N. N. Suartini ${ }^{3}$ \\ Program Studi Pendidikan Bahasa Jepang, \\ Universitas Pendidikan Ganesha \\ Singaraja, Indonesia \\ e-mail: sudarsanawayan94@gmail.com \\ krishna.adnyani@undiksha.ac.id nnsuartini@undiksha.ac.id
}

\begin{abstract}
Abstrak
Penelitian ini bertujuan untuk meningkatkan penguasaan kosakata bahasa Jepang siswa dengan penerapan metode picture and picture, dan mendeskripsikan respons siswa terhadap penerapan metode picture and picture dalam meningkatkan penguasaan kosakata bahasa Jepang. Subjek dalam penelitian ini adalah siswa kelas X AP 2 SMKN 1 Nusa Penida tahun ajaran 2017/2018 yang berjumlah 36 orang. Metode pengumpulan data yang digunakan adalah wawancara, observasi, tes, dan kuesioner. Data hasil penelitian dianalisis dengan menggunakan teknik analisis data deskriptif kuantitatif dan kualitatif. Pada hasil pretest menunjukkan kondisi awal siswa dengan persentase ketuntasan $14 \%$ dengan rata-rata nilai 44 . Sedangkan pada siklus I, persentase ketuntasan siswa adalah $53 \%$, dengan rata-rata nilai 67 . Pada siklus II, persentase ketuntasan siswa adalah $92 \%$, dengan rata-rata nilai 81 . Serta respons siswa terhadap penerapan metode picture and picture tergolong sangat positif dengan skor rata-rata 41,5 pada siklus I dan 41,7 pada siklus II. Hasil penelitian menunjukkan bahwa penerapan metode picture and picture dapat meningkatkan penguasaan kosakata bahasa Jepang siswa. Hal ini disebabkan oleh pengaruh dari gambar-gambar kosakata yang efektif, dapat menumbuhkan minat belajar siswa dan fokus dalam pembelajaran di kelas.
\end{abstract}

Kata kunci: metode pembelajaran, picture and picture, penguasaan kosakata bahasa Jepang

\section{要旨}

本研究の目的は、Picture

and

Picture方法の使用が学習者の日本語の語彙を向上させるために効果があるか、日本語の語彙を向上さ せることでPicture and

Picture方法の使用に対する学習者の反応を明示寸ることである。本研究は 2 周期に渡る実践研究であ る。研究対象は 2017 年度ヌサペニダ宿泊設備高等学校観光コース 10 年生 2 組の36名である。デ ータの収集は、インタビュー、観察、テスト、およびで行った。また、データの分析は定性的および 定量的記述法を使用した。これは

予備テストで標準を越えた学習者は $14 \%$ で、平均点が44点だったのに対し、第一周期終了時では $53 \%$ 、平均点が67点、第二周期終了時では $92 \%$ ，平均点が 81 点に上がったことからいえる、Picture and Picture方法の使用に対する学習者の反応は良好であった。第一周期では学習者の反応の平均点は

41,5で、良好であった。第二周期では学習者の反応の平均点は $41,7,7$ 点で、良好で あった。本研究の結果は、Picture and Picture 方法の使用は学習者の日本語の語彙を向上させた。それは効果的ながその語彙の写真影響からによっ て引き起こさせる、深刻なと学習の関心成長するができる。

キーワード：方法、Picture and Picture、語彙

\section{Pendahuluan}

Pembelajaran bahasa Jepang di Indonesia pada tingkat SMA/SMK sederajat dalam penyelenggaraanya pada saat ini berupa mata pelajaran wajib, pilihan, bahkan dijadikan sebagai mata pelajaran ekstrakurikuler. Bahasa Jepang pada sekolah kejuruan, umumnya diselenggarakan pada bidang teknik, pariwisata, perhotelan, atau bidang perkantoran. Pada tingkat perguruan tinggi(PT), pendidikan bahasa Jepang dilaksanakan berupa 
jurusan/program studi dan ada juga diajarkan sebagai mata kuliah tambahan. Pada universitas umum, bobot mata kuliah yang berhubungan dengan kesusastraan mendapat perhatian yang lebih karena bahasa Jepang diajarkan di bawah fakultas sastra. Berbeda dengan lembaga kependidikan yang menyelenggarakan pengajaran bahasa Jepang, bobot mata kuliah keguruan atau kependidikan yang lebih diperhatikan (dalam Sutedi, 2009: 29).

Secara umum, pembelajaran bahasa Jepang pada tingkat SMA bermaterikan kosakata, huruf, tata bahasa, dan pengenalan budaya Jepang. Dalam pembelajaran bahasa, terdapat empat keterampilan yang ditekankan yakni keterampilan membaca, keterampilan berbicara, keterampilan menyimak, dan keterampilan menulis. Keempat keterampilan berbahasa tersebut tidak dapat dipisahkan dan harus dikuasai oleh siswa agar mampu menggunakan bahasa tersebut untuk berkomunikasi dengan baik, baik secara lisan maupun tulisan. Dalam praktik pengajarannya, guru dituntut untuk lebih menekankan keempat keterampilan tersebut. Umumnya, tujuan belajar bahasa yaitu agar siswa mampu menggunakan bahasa dengan baik untuk berkomunikasi baik secara lisan maupun tulisan. Keterampilan berbahasa yang dimiliki dapat ditentukan pada seberapa banyak kosakata yang diketahuinya. Begitu juga halnya dalam belajar bahasa Jepang, siswa dituntut untuk menguasi keempat keterampilan berbahasa tersebut dan salah satunya adalah dengan memperbanyak penguasaan kosakata bahasa Jepang.

Kosakata merupakan sebuah komponen yang sangat penting dalam keterampilan berbahasa. Dengan banyaknya kosakata yang dimiliki maka akan mempermudah penutur melakukan komunikasi. Sesuai dengan teori yang dikemukakan oleh Tarigan (1989) bahwa semakin kaya kosakata yang dimiliki oleh seseorang semakin besar pula keterampilan seseorang dalam berbahasa. Sehubungan dengan keterampilan berbahasa seperti yang telah disebutkan di atas, permasalahan terjadi pada siswa kelas $\mathrm{X}$ program keahlian Akomodasi Perhotelan 2 di SMKN 1 Nusa Penida. Sekolah tersebut merupakan SMK negeri yang dijadikan sebagai tempat penelitian.

Alasan dilakukannya penelitian ini karena ditemukan masalah bahwa pelaksanaan pembelajaran bahasa Jepang yang terjadi masih belum optimal, terutama dalam hal penguasaan kosakata. Karena dalam proses menyusun kalimat dalam pembelajaran, sangat memerlukan penguasaan kosakata sebagai dasarnya. Hal ini disebabkan karena proses pembelajaran guru berperan sentral sebagai pusat pembelajaran dan siswa cenderung pasif dalam proses pembelajaran sehingga siswa kesulitan dalam memahami dan mengingat kosakata yang dicatat di papan tulis, karena tanpa media lain seperti gambar atau video pembelajaran. Fasilitas belajar kurang seperti; LCD (Liquid Crystal Display) yang tersedia hanya beberapa saja dan hanya digunakan untuk kegiatan sekolah. Jangkauan Wi-Fi (Wireless Fidelity) hanya untuk memenuhi kebutuhan operator sekolah. Sumber belajar dalam proses pembelajaran guru hanya menggunakan buku ajar berjudul "bahan evaluasi belajar bahasa Jepang" sebagai sumber belajar karena keterbatasan bahan ajar yang dimiliki guru maupun yang disediakan di perpustakaan. Media pembelajaran yang digunakan oleh guru hanya berpatokan pada buku ajar tersebut, sehingga kosakata yang disampaikan sulit dimengerti oleh siswa, dan siswa kesulitan dalam mengidentifikasi kosakata mana yang termasuk ke dalam kata benda, kata kerja, kata sifat, kata keterangan dan lain-lain.

Rata-rata hasil belajar bahasa Jepang siswa kelas X AP 2 SMKN 1 Nusa Penida belum mencapai skor Kriteria Ketuntasan Minimal (KKM) yang ditetapkan, khususnya dalam hal penguasaan kosakata bahasa Jepang. Dari data hasil pretest yang dilakukan pada waktu Sabtu, 21 Oktober 2017 Pukul 10.20 WITA, diperoleh hanya 5 orang dengan ketuntasan $14 \%$ dari total 36 siswa ikut pretest yang memenuhi KKM dengan rata-rata skor hasil belajar siswa sebesar 44 dari skor KKM yang ditetapkan sebesar 70 . Selain dari faktor kesulitan yang dihadapi oleh siswa dalam belajar, hal ini juga dikarenakan metode pembelajaran yang diterapkan oleh guru masih menggunakan metode konvensional yaitu ceramah. Hal itu terlihat pada proses pembelajaran yang dilakukan masih terpusat pada guru. Segala bentuk informasi/materi pembelajaran disajikan oleh guru tanpa adanya stimulus maupun partisipasi aktif dari siswa sehingga kondisi kelas cenderung pasif.

Tenaga pengajar bahasa Jepang, diharapkan untuk mampu menerapkan pembelajaran yang menyenangkan, inovatif, kreatif, dan aktif sehingga mampu menyalurkan materi-materi 
pelajaran dengan baik kepada siswa. Menyenangkan diartikan sebagai suatu pembelajaran yang tidak membosankan dan mampu membangkitkan minat dan perhatian siswa pada pelajaran. Inovatif berarti setiap pembelajaran harus memberikan sesuatu yang baru, berbeda dan selalu menarik minat peserta didik. Kreatif berarti pembelajaran yang mengarahkan peserta didik untuk menghasilkan sesuatu atau dapat menyelesaikan suatu masalah dengan menggunakan kreatifitas siswa itu sendiri yang diperoleh dari proses pembelajaran. Aktif berarti pembelajaran harus fokus pada konsep student center yang berarti siswa lebih banyak berperan aktif dalam pembelajaran.

Diperlukan suatu pembelajaran yang memiliki ciri khas pembelajaran yang menarik, inovatif, kreatif, dan aktif. Oleh karena itu, diperlukan perencanaan mengenai pemilihan metode pembelajaran yang sesuai untuk diterapkan dalam pembelajaran. Salah satu metode pembelajaran yang memiliki ciri menyenangkan, inovatif, kreatif, dan aktif yaitu metode picture and picture. Menurut Hamdani (dalam Dewi, 2013:4) menyatakan bahwa picture and picture merupakan suatu metode belajar menggunakan gambar yang dipasangkan atau diurutkan menjadi urutan logis.

Suprijono (dalam Dewi, 2013:4) mengemukakan langkah-langkah pembelajaran picture and picture, yaitu; (a) guru menyampaikan kompetensi yang ingin dicapai, (b) guru menyajikan materi sebagai pengantar, (c) guru menunjukkan/memperlihatkan gambargambar yang berkaitan dengan materi, (d) guru menunjuk/memanggil siswa secara bergantian memasang/mengurutkan gambar-gambar menjadi urutan yang logis, (e) guru menanyakan alasan/dasar pemikiran urutan gambar tersebut, $(f)$ guru memulai menanamkan konsep/materi sesuai dengan kompetensi yang ingin dicapai, (g) kesimpulan/rangkuman.

Berdasarkan masalah yang dihadapi siswa kelas X AP 2 SMKN 1 Nusa Penida, maka dilakukan penelitian untuk mengetahui karakteristik siswa yang cenderung pasif dalam pembelajaran agar menjadi aktif, melalui penerapan metode picture and picture sehingga pembelajaran menjadi menyenangkan dan penguasaan bahasa Jepang siswa meningkat. Penelitian ini dilakukan juga untuk mengetahui respons siswa kelas X AP 2 SMKN 1 Nusa Penida terhadap penerapan metode picture and picture ini dalam meningkatkan kemampuan penguasaan kosakata bahasa Jepang mereka.

Untuk melaksanakan kegiatan penelitian ini lebih lanjut, peneliti perlu menyusun rumusan masalah untuk memudahkan pelaksanaanya. Berdasarkan latar belakang masalah di atas, permasalahan dapat dirumuskan sebagai berikut. (1) Apakah dengan penerapan metode picture and picture dapat meningkatkan penguasaan kosakata bahasa Jepang siswa kelas X AP 2 SMKN 1 Nusa Penida tahun ajaran 2017/2018?, (2) Bagaimanakah respons siswa kelas X AP 2 SMKN 1 Nusa Penida terhadap penerapan metode picture and picture pada pembelajaran kosakata bahasa Jepang?.

Sedangkan tujuan dari penelitian ini adalah untuk meningkatkan penguasaan kosakata bahasa Jepang siswa kelas X AP 2 SMKN 1 Nusa Penida tahun ajaran 2017/2018 melalui penerapan metode picture and picture dan untuk mendeskripsikan respons siswa kelas $X$ AP 2 SMKN 1 Nusa Penida terhadap penerapan metode picture and picture pada pembelajaran kosakata bahasa Jepang.

\section{Metode}

Rancangan penelitian merupakan strategi mengatur latar penelitian agar memperoleh data yang valid sesuai dengan karakteristik variabel dan tujuan dari penelitian. Menurut McNiff (dalam Kanca, 2010:108) penelitian tindakan kelas merupakan bentuk penelitian reflektif yang dilakukan oleh guru sendiri yang hasilnya dapat dimanfaatkan sebagai alat untuk pengembangan kurikulum, pengembangan sekolah, pengembangan keahlian mengajar, dan sebagainya. Secara lebih luas penelitian tindakan diartikan sebagai penelitian yang berorientasi pada penerapan tindakan dengan tujuan peningkatan mutu atau pemecahan masalah pada sekelompok subjek yang diteliti dan mengamati tidakan keberhasilan atau akibat tindakannya, untuk kemudian diberikan tindakan lanjutan yang bersifat penyempurnaan tindakan atau penyesuaian dengan kondisi atau situasi sehingga diperoleh hasil yang lebih baik. Penelitian tindakan kelas terdiri atas beberapa siklus yang dilaksanakan secara bertahap. Siklus 1 terdiri atas refleksi awal, rencana tindakan 1, 
pelaksanaan tindakan 1, obseravasi, evaluasi, dan refleksi. Bila hasil evaluasi tindakan 1 belum maksimal, dilanjutkan dengan membuat perencanaan 2, dengan urutan seperti siklus 1. Siklus ini dapat dilakukan berkali-kali sampai kondisi yang ingin diperbaiki dapat dinyatakan sudah baik.

Penelitian ini dilakukan di SMKN 1 Nusa Penida tahun ajaran 2017/2018 yang berlokasi di Jalan Pendidikan, Desa Ped, Kecamatan Nusa Penida, Kabupaten Klungkung. Subjek dalam penelitian ini adalah siswa kelas X AP 2 SMKN 1 Nusa Penida. Dipilinnya subjek tersebut karena siswa kelas X AP 2 mengalami kesulitan dalam penguasaan kosakata bahasa Jepang. Hal ini sebabkan karena model pembelajaran yang digunakan konvensional. Sedangkan objek penelitian merupakan hal yang dikaji dalam sebuah penelitian. Objek pertama dalam penelitian ini mencakup tindakan yang dilakukan dalam penelitian, yaitu aktivitas siswa dalam mengikuti pembelajaran yang menerapkan metode pembelajaran picture and picture. Sedangkan objek yang kedua mencakup sesuatu yang diharapkan mengalami perubahan atau perbaikan, yaitu penguasaan kosa kata bahasa Jepang.

Untuk mengukur hasil belajar siswa dalam pembelajaran kosakata Jepang di kelas $\mathrm{X}$ AP 2 secara individual, skor ketuntasan individual $(\mathrm{KI})$ dapat diperoleh melalui rumus:

$\mathrm{KI}=($ Nilai yang Diperoleh Siswa)/(Skor Maksimal) $\times 100$

Nilai yang diperoleh siswa dikonversikan ke dalam pedoman konversi skor berikut.

Tabel 1. Kriteria Ketuntasan Siswa

\begin{tabular}{cc}
\hline Skor & Keterangan \\
\hline $84-100$ & Tuntas \\
$70-83$ & Tuntas \\
$64-69$ & Belum Tuntas \\
$50-63$ & Belum Tuntas \\
$0-49$ & Belum Tuntas \\
\hline
\end{tabular}

Siswa dikatakan tuntas apabila nilai minimal yang diperoleh siswa adalah 70 . Secara klasikal, dikatakan tuntas apabila $85 \%$ dari jumlah siswa yang ada di kelas tersebut memperoleh nilai 70 atau lebih. Ketuntasan klasikal (KK) dapat diperoleh melalui rumus:

$\mathrm{KK}=$ (Jumlah Siswa yang Tuntas)/(Jumlah Seluruh Siswa) $\times 100$

Apabila $85 \%$ dari jumlah siswa memperoleh nilai 70 ke atas, penelitian sudah dapat dikatakan tuntas dan penelitian dapat dihentikan.

Data hasil wawancara tentang respons siswa dianalisis dengan teknik analisis kualitatif, yaitu data tersebut dideskripsikan sesuai pedoman dan instrumen yang telah ditetapkan. Sementara itu, data respons siswa hasil kuesioner dianalisis dengan teknik kuantitatif. Tahapan untuk mengukur respons siswa dalam pembelajaran kosakata bahasa Jepang melalui penerapan metode picture and picture adalah sebagai berikut. (1) Mencari skor maksimal ideal (SMI) kuesioner yang diberikan. SMI dicari dengan jalan menghitung jumlah item yang diberikan serta bobot masing-masing item. (2) Mencari rata-rata ideal (Mi) untuk kuisioner tersebut dengan rumus :

$\mathrm{Mi}=1 / 2$ (skor maksimal ideal + skor minimal ideal). (3) Mencari standar deviasi ideal (SDi) untuk kuisioner tersebut dengan rumus: SDi = $1 / 3 \times$ Mi. (4) Membuat pedoman konversi dengan ketentuan :

Tabel 2. Pedoman Konversi Skor Respons Siswa

\begin{tabular}{cc}
\hline Skor & Kriteria \\
\hline $\bar{X} \geq M i+1,5$ Sdi & Sangat positif
\end{tabular}




$$
\begin{array}{cc}
M i+0,5 \text { SDi }<\bar{X}<M i+1,5 \text { Sdi } & \text { Positif } \\
M i-0,5 \text { SDi } i \bar{X}<M i+1,5 \text { Sdi } & \text { Cukup positif } \\
M i-0,5 S D i<\bar{X}<M i-1,5 \text { Sdi } & \text { Kurang positif } \\
\bar{X}<M i-1,5 S d i & \text { Sangat kurang positif }
\end{array}
$$

Nurkancana dan Sumartana (1983:80

Keterangan :

$-X=\left(\sum \sum_{i=1} n\right) / N$

${ }^{-} \mathrm{X}=$ Jumlah rata-rata respons siswa

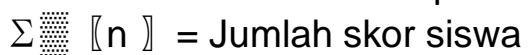

$\mathrm{N}=$ Jumlah siswa yang mengisi kuesioner

$\mathrm{Mi}=$ Mean ideal

Skor tertinggi ideal untuk respons siswa melalui penyebaran angket adalah 50, sedangkan skor terendah ideal adalah 10. Oleh karena itu, diperoleh Mi dan SDi sebagai berikut.

$$
\begin{aligned}
& \text { Mi }=1 / 2(50+10) \\
& =1 / 2(60) \\
& =30 \\
& \text { SDi }=1 / 3 \times(30) \\
& =10
\end{aligned}
$$

Penelitian mengenai respons siswa terhadap penerapan metode picture and picture dianggap berhasil apabila jumlah siswa yang merespons positif lebih banyak daripada jumlah siswa yang merespons negatif.

\section{Hasil dan Pembahasan}

Hasil penelitian pada penelitian ini diperoleh dari pengamatan (observasi), tes, kuesioner, dan wawancara melalui pelaksanaan rencana penelitian tindakan kelas. Berdasarkan hasil pengamatan sebelum diterapkannya metode picture and picture diperoleh hasil bahwa Guru

hanya menggunakan buku ajar bahan evaluasi belajar bahasa Jepang saja saat mengajar. Selain itu, penguasaan kosakata bahasa Jepang siswa juga masih rendah. Hal tersebut terlihat dari hasil pretest yang dilakukan, jumlah siswa yang tuntas sebanyak 5 orang dengan persentase $14 \%$. Sedangkan siswa yang masih berada di bawah KKM berjumlah 31 orang dengan persentase $86 \%$. Nilai tertinggi yang diperoleh siswa adalah 87 dan nilai terendah 20. Jumlah nilai dari siswa secara keseluruhan sebesar 1595 sehingga diperoleh rata-rata sebesar 44 . Dalam pemetaan skor, nilai 44 termasuk ke dalam kategori kurang sehingga penguasaan kosakata Jepang siswa perlu ditingkatkan lagi.

Selanjutnya, tindak lanjut dari penelitian yang dilakukan adalah dengan melaksanakan siklus. Dalam penelitian tindakan kelas ini menerapkan dua siklus. Setiap siklusnya terdiri atas refleksi awal, perencanaan tindakan, observasi, evaluasi, dan refleksi.

Siklus I dilaksanakan dalam dua sesi, dua kali pelaksanaan tindakan dan akhir tindakan kedua diadakan evaluasi. Berikut ini akan diuraikan data hasil posttest siklus I setelah diterapkannya metode picture and picture. Diperoleh data bahwa 19 orang atau dengan persentase $53 \%$ telah berhasil memperoleh nilai yang memenuhi nilai kriteria ketuntasan minimal (KKM) dan sisanya sebanyak 17 orang atau dengan persentase $47 \%$ masih belum mampu memenuhi nilai kriteria ketuntasan minimal (KKM) setelah diterapkannya metode picture and picture. Jumlah nilai keseluruhan adalah 2418 sehingga diperoleh rata-rata sebesar 67 . Nilai tertinggi yang diperoleh siswa adalah 93 dan nilai terendah yang diperoleh siswa adalah 40.

Untuk mengetahui respons siswa terhadap penerapan metode picture and picture dalam meningkatkan penguasaan kosakata bahasa Jepang, siswa diberikan kuesioner tertutup. Pada kuesioner tertutup terdapat 9 pernyataan yang harus dijawab oleh siswa mengenai 
penerapan metode picture and picture untuk meningkatkan penguasaan kosakata bahasa Jepang. Siswa diminta untuk mengisi tiap-tiap pernyataan dengan jawaban SS (sangat setuju), S (setuju), KS (kurang setuju), TS (tidak setuju) dan STS (sangat tidak setuju). Pada masing-masing jawaban dari pernyataan tersebut memiliki bobot nilai yang berbeda-beda yaitu ; apabila jawaban SS (sangat setuju) poin $5, \mathrm{~S}$ (setuju) poin $4, \mathrm{R}$ (ragu) poin 3 , TS (tidak setuju) poin 2 dan STS (sangat tidak setuju) poin 1. Berdasarkan data-data yang telah terkumpul, kemudian disesuaikan dengan analisis data yang ada, didapatkan total perolehan skor yang terkumpul adalah 1494. Rata-ratanya adalah 41,5 sehingga respons siswa tergolong kedalam respons yang sangat positif.

Pelaksanaan pembelajaran sudah berjalan sesuai dengan prosedur penelitian yang telah disusun. Siswa yang memperoleh nilai diatas nilai KKM pada tes siklus I adalah 19 orang siswa atau dengan persentase ketuntasan 53\%. Hal ini menunjukkan bahwa pada siklus I belum mencapai kriteria keberhasilan yaitu $85 \%$. Untuk mencapai kriteria keberhasilan $85 \%$ maka akan dilanjutkan kembali dengan siklus II.

Terkait dengan penelitian, di dalam pelaksanaannya tidak terlepas dari kendalakendala yang dihadapi. Adapun kendala-kendala yang muncul dari pelaksanaan siklus I ini diantaranya; (1) pada sesi pertama siswa masih beradaptasi dengan metode picture and picture sehingga siswa terlihat bingung dengan instruksi yang diberikan. (2) pada sesi menampilkan gambar-gambar kosakata, sebagian kecil siswa tidak fokus pada proses pengajaran tersebut, cenderung siswa sibuk diluar konteks pelajaran. (3) kertas yang digunakan untuk menampilkan gambar-gambar kosakata tipis, mudah terlipat, gambar kosakata menjadi terlihat transparan, sehingga gambar kosakata yang ditampilkan kurang jelas.

Dari hasil refleksi pada siklus I, untuk mencegah kembali terjadinya kesalahankesalahan pada pelaksanaan tindakan siklus I, maka akan dilakukan perbaikan-perbaikan yang akan ditekankan pada pelaksanaan siklus II. Perbaikan tersebut diantaranya; (1) memberikan penekanan-penekanan penjelasan pada hal yang masih dianggap kurang dimengerti. (2) memberikan kesempatan kepada siswa yang ribut membicarakan hal di luar pelajaran untuk maju ke depan kelas untuk memasangkan gambar, ini bertujuan agar meminimalisir keributan, dan membuat siswa yang kurang fokus pada pembelajaran menjadi fokus. (3) melapisi kertas bergambar kosakata, sehingga gambar kosakata yang ditampilkan menjadi lebih tebal, tidak mudah terlipat, dan gambar kosakata yang ditampilkan terlihat lebih jelas.

Siklus II juga dilaksanakan dalam dua sesi. Pada siklus II ini, segala hal yang terjadi pada refleksi siklus I menjadi acuan untuk memperbaiki masalah pada siklus I. Proses pada siklus II sesuai dengan proses siklus I. Pada tahap refleksi awal siklus II, peneliti merefleksi hasil siklus I yang telah dilaksanakan sebelumnya. Untuk itu, pelaksanaan tindakan pada siklus II ini merupakan penyempurnaan dari tindakan yang telah dilaksanakan pada siklus I. Hasil observasi selama proses penerapan metode picture and picture terlihat lebih baik dari sebelumnya, baik dari hasil obervasi terhadap aktivitas guru maupun hasil observasi aktivitas siswa. Dalam siklus II ini diperoleh hasil evaluasi yaitu hasil posttest siklus II. Adapun hasil dari pelaksanaan posttest II yaitu diperoleh data bahwa 33 orang atau dengan persentase $92 \%$ telah berhasil memperoleh nilai yang memenuhi kriteria ketuntasan minimal (KKM) dan sisanya sebanyak 3 orang atau dengan persentase $8 \%$ masih belum mampu memenuhi nilai kriteria ketuntasan minimal (KKM) setelah diterapkannya metode picture and picture. Nilai tertinggi yang diperoleh siswa adalah 100 dan nilai terendah yang diperoleh siswa adalah 60 . Rata-rata yang diperoleh pada Posttest II adalah 81.

Perbandingan antara tingkat ketuntasan pada Pretest, Posttest I dan Posttest II pada siswa kelas X AP 2 SMKN 1 Nusa Penida adalah sebagai berikut. 


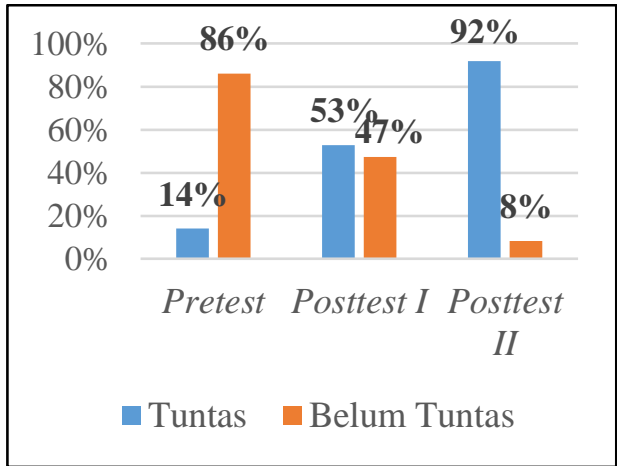

Gambar 1. Perbandingan Hasil Pretest, Posttest I, dan Posttest II

Hasil data respons siswa melalui kuesioner yang telah diberikan kepada siswa, berdasarkan data-data yang telah terkumpul kemudian disesuaikan dengan analisis data yang ada, total perolehan skor yang terkumpul adalah 1500 dengan jumlah rata-ratanya adalah 41,7. Dengan demikian, respons siswa tergolong kedalam respons yang sangat positif.

Pelaksanaan pembelajaran sudah berjalan sesuai dengan prosedur penelitian yang telah disusun. Siswa yang memperoleh nilai diatas nilai KKM pada tes siklus II sebanyak 33 orang atau dengan persentase ketuntasan $92 \%$. Hal ini menunjukkan bahwa pada siklus II sudah mencapai kriteria keberhasilan yaitu $85 \%$ sehingga penelitian dapat dihentikan.

Terkait dengan penelitian, di dalam pelaksanaannya tidak terlepas dari kendalakendala yang dihadapi. Adapun kendala-kendala yang muncul dari pelaksanaan siklus II ini antara lain; (1) penyesuaian media gambar dengan materi bulan (月) dan tanggal (日) rumit. (2) ada 3 siswa yang nilainya masih belum mencapai KKM yang telah ditentukan. Berdasarkan hasil pretest, posstest I, posstest II, 3 siswa ini sudah ada peningkatan nilai setiap pelaksanaan tes, tetapi nilai mereka masih dibawah KKM. Tidak ada sebab 3 siswa ini nilai belum mencapai KKM. Siswa sudah antusias dalam setiap pertemuan sebanyak 6 kali dan hasil kuesioner respons siswa terhadap penerapan metode picture and picture adalah sangat positif.

\section{PEMBAHASAN}

Berdasarkan temuan penelitian yang dilakukan pada kelas X AP 2 di SMKN 1 Nusa Penida pada mata pelajaran bahasa Jepang dengan menerapkan metode picture and picture dapat meningkatkan penguasan kosakata bahasa Jepang siswa. Hal ini ditunjukan dengan adanya peningkatan hasil belajar siswa dari siklus I ke siklus II. Peningkatan ini terjadi karena penerapan metode pembelajaran dalam penelitian ini dilakukan dengan langkahlangkah sesuai dengan metode picture and picture, dimulai dari perencanaan pembelajaran (RPP) yang dibuat sesuai metode pembelajaran, menyiapkan gambar-gambar yang akan ditunjukan kepada siswa dan berlatih penguasan kosakata.

Pembelajaran picture and picture ini, membantu kesulitan-kesulitan siswa dalam pembelajaran. Hal ini didukung oleh pemilihan media gambar yang digunakan. Perhatian siswa menjadi lebih fokus pada pelajaran, karena gambar-gambar yang dipilih merupakan gambar-gambar yang menarik sehingga juga dapat memacu motivasi belajar siswa.

Temuan ini sejalan dengan Shoimin (2014:123), bahwa gambar sangat penting digunakan untuk memperjelas pengertian. Melalui gambar, siswa mengetahui hal-hal yang belum pernah dilihatnya. Gambar dapat membantu guru mencapai tujuan intruksional karena selain merupakan media yang murah dan mudah diperoleh, juga dapat meningkatkan keaktifan siswa.

Dalam menerapkan metode picture and picture mampu meningkatkan pembendaharaan kosakata siswa karena kosakata yang diajarkan tidak hanya ada di buku. Nantinya akan berpengaruh terhadap kemampuan siswa dalam keterampilan berbahasa khususnya bahasa Jepang. Hal ini sesuai dengan pendapat Tarigan (1989) yaitu semakin kaya kosakata yang dimiliki oleh seseorang maka semakin besar pula keterampilan seseorang dalam berbahasa. 
Apabila pembendaharaan kosakata seseorang banyak, maka akan lebih mudah berkomunikasi dan menyusun kalimat-kalimat secara tepat.

Berdasarkan hasil yang diperoleh dalam penelitian ini, penerapan metode picture and picture dalam meningkatkan kemampuan penguasaan kosakata bahasa Jepang siswa kelas $X$ AP 2 SMKN 1 Nusa Penida telah mencapai kriteria keberhasilan pada siklus I dengan persentase $53 \%$, sedangkan pada siklus II dengan persentase ketuntasan $92 \%$. Pada siklus I masih belum mencapai kriteria keberhasilan. Tetapi pada siklus II sudah mencapai kriteria keberhasilan yaitu $85 \%$ dan penelitian dapat dihentikan. Temuan ini didukung teori dari Depdikbud (dalam Trianto, 2010:241) yang menyatakan bahwa penelitian dikatakan tuntas apabila $\geq 85 \%$ siswa memenuhi nilai standar KKM. Pada siklus II, 33 siswa mendapatkan nilai tuntas. Hal ini juga dikarenakan rencana pelaksanaan pembelajaran (RPP) dan langkah-langkah penerapan metode pembelajaran yang diterapkan dan diikuti sudah sesuai dengan prosedur.

Jadi keberhasilan penelitian ini mampu meningkatkan penguasaan kosakata bahasa Jepang siswa kelas X AP 2 SMKN 1 Nusa Penida adalah pengaruh dari gambar-gambar kosakata yang menarik perhatian siswa sehingga lebih fokus terhadap mata pelajaran bahasa Jepang. Selain menarik perhatian siswa, gambar-gambar kosakata tersebut membangkitkan semangat siswa untuk lebih giat belajar.

\section{IMPLIKASI}

Pembelajaran bahasa Jepang dengan metode picture and picture dapat dijadikan bahan acuan untuk mengadakan penelitian selanjutnya dengan sudut permasalahan yang berbeda. Selain itu, metode picture and picture ini dapat diterapkan oleh guru-guru yang memegang mata pelajaran selain bahasa Jepang. Berdasarkan hasil penelitian diperoleh implikasi yaitu sebagai berikut.

Penerapan metode picture and picture mampu meningkatkan hasil belajar siswa khususnya dalam mengingat kosakata bahasa Jepang. Hal ini didukung oleh pemilihan media gambar yang digunakan. Perhatian siswa menjadi lebih fokus pada pelajaran, karena gambar-gambar yang dipilih merupakan gambar-gambar yang menarik sehingga juga dapat memacu motivasi belajar siswa yang menyebabkan rata-rata hasil dan motivasi belajar meningkat. Oleh karena itu, dalam upaya meningkatkan kualitas pembelajaran bahasa Jepang siswa metode picture and picture ini bisa terus dikembangkan.

\section{Simpulan dan Saran}

Berdasarkan hasil penelitian dan pembahasan dapat diperoleh kesimpulan sebagai berikut. (1) penerapan metode picture and picture dapat meningkatkan penguasaan kosakata bahasa Jepang pada siswa kelas X AP 2 SMKN 1 Nusa Penida. Peningkatan penguasaan kosakata bahasa Jepang siswa berdasarkan dari hasil pretest, posttest siklus I, hingga posttest siklus II. Hasil pretest menunjukkan kondisi awal siswa dengan rata-rata nilai yang diperoleh siswa adalah 20 dengan persentase ketuntasan 14\%. Setelah pelaksanaan siklus I, rata-rata nilai yang diperoleh siswa meningkat menjadi 67 dengan persentase ketuntasan 53\%. Setelah pelaksanaan siklus II, rata-rata nilai yang diperoleh siswa meningkat menjadi 81 dengan persentase ketuntasan 92\%. (2) tanggapan siswa kelas X AP 2 SMKN 1 Nusa Penida terhadap penerapan metode picture and picture untuk meningkatkan penguasaan kosakata bahasa Jepang pada siklus I tergolong sangat positif dengan rata-rata skor 41,5 . Sedangkan respons siswa setelah diterapkannya metode picture and picture pada siklus II juga tergolong sangat positif dengan rata-rata skor 41,7.

Sebagai tindak lanjut dari penelitian ini terdapat beberapa saran yang ditujukan terhadap pihak-pihak yang terkait sebagai berikut; (1) dari penelitian ini diharapkan dapat memberikan motivasi kepada guru untuk melakukan proses pembelajaran yang inovatif dan penggunaan media pembelajaran yang variatif sehingga dapat meningkatkan pemahaman serta meningkatkan prestasi belajar siswa. Salah satunya dengan menerapkan metode picture and picture. (2) dari penelitian ini diharapkan dapat memberikan motivasi kepada siswa dalam mempelajari bahasa Jepang serta lebih aktif dalam mengikuti proses pembelajaran di sekolah, sehingga dapat meningkatkan pemahaman serta meningkatkan 
prestasi belajar siswa khususnya dalam pembelajaran kosakata bahasa Jepang. (3) diharapkan agar penelitian lain dapat mengembangkan ide kreatifitasnya demi metode pembelajaran dan pelaksanaan pembelajaran yang efektif khususnya dalam pembelajaran bahasa Jepang. Metode ini tidak khusus digunakan dalam penelitian kemampuan penguasaan kosakata, tetapi dapat juga diterapkan pada keterampilan berbahasa lainnya seperti mengarang, dan pola kalimat.

\section{Daftar Pustaka}

Dewi, Frisca Kumala. 2013. "Penerapan Model Picture and Picture Untuk Meningkatkan Keterampilan Menulis Deskripsi Pada Siswa Kelas II SDN Bringin 02 Semarang". Skripsi (tidak diterbitkan). Universitas Negeri Semarang.

Kanca, I Nyoman. 2010. Metode Penelitian Pengajaran Pendidikan Jasmani Dan Olah Raga. Singaraja: Tidak Diterbitkan.

Nurkancana, Wayan dan Sunartana. 1992. Evaluasi Hasil Belajar. Surabaya: Usaha Nasional.

Shoimin, Aris. 2014. 68 Model Pembelajaran Inovatif dalam Kurikulum 2013. Yogyakarta: AR-RUZZ Media.

Sutedi, Dedi. 2003. Dasar-dasar Linguistik Bahasa Jepang. Bandung: Humaniora.

Trianto. 2010. Mendesain Model Pembelajaran Inovatif-Progresif: Konsep, Landasan, dan Implementasinya Pada Kurikulum Tingkat Satuan Pendidikan (KTSP). Jakarta: Prenada Media Group. 